\title{
Upaya Peningkatan Pembelajaran Keterampilan dan Penguasaan Teknik Dasar Atletik, Lari Cepat/ Sprint Melalui Sirkuit Run 20 Meter Tukar Tempat, pada Peserta Didik Kelas : IX D Mts Negeri Model Sorong Tahun 2017-2018.
}

\author{
Ansori \\ Madrasah Tsanawiyah Negeri Model Sorong
}

\begin{abstract}
Abstrak: Penelitian yang dilakukan merupakan penelitian tindakan kelas yang terdiri dari dua siklus. Teknik analisis yang dilakukan adalah kuantitatif- kualitatif. Data kemampuan peserta didik didapat dari hasil tes keterampilan dan penguasaan peserta didik dan guru didapat dari hasil observasi. Sebagai sumber data adalah kelas IX- D semester 2 Sorong tahun pelajaran 2017-2018 dengan peserta didik sebanyak 26 orang. Pada siklus 1, pertemuan satu kali (1) dengan menggunakan langkah- langkah pembelajaran dalam strategi pembelajaran komando dan pada siklus II, pertemuan satu kali (1), langkah- langkah pembelajaran yang digunakan adalah melalui strategi pembelajaran Sirkuit Run 20 Meter Tukar Tempat. Hasil penelitian menunjukkan bahwa strategi pembelajaran melalui Sirkuit Run 20 Meter Tukar Tempat, dapat meningkatkan keterampilan dan penguasaan teknik dasar, dapat memecahakan masalah Penjasorkes pada materi Lari cepat/ Sprint di kelas IX-D MTs. Negeri Sorong. Pada siklus 1 ketuntasan kelas secara klasikal adalah 66,7\% meningkat menjadi 85\% pada siklus 2. Sedangkan secara individu, dari 24 peserta didik, terdapat 2 peserta didik yang belum mencapai nilai minimal 75, tetapi mereka sudah mengalami peningkatan nilai. Untuk kelima peserta didik ini diberikan pembelajaran remedial yang dilaksanakan setelah penelitian ini. Selain itu, diperoleh hasil pengamatan aktivitas peserta didik dan guru yang menunjukkan peserta didik dan guru aktif selama pembelajaran.
\end{abstract}

Kata Kunci : teknik dasar lari cepat/ sprint,sirkuit run tukar tempat

\section{Pendahuluan}

Perkembangan ilmu pengetahuan dan teknologi, pengaruh global, serta seni dan Undang-undang Republik Indonesia No. 20 Tahun 2003 tentang Sistem Pendidikan Nasional, Bab V pasal 12, butir (1) bagian f, menegaskan bahwa setiap peserta didik pada setiap satuan pendidikan berhak menyelesaikan program pendidikan sesuai dengan kecepatan belajar masing-masing dan tidak menyimpang dari ketentuan batas waktu yang ditetapkan. Oleh karena itu, guru perlu mengupayakan strategi, pendekatan, metode maupun model pembelajaran sehingga peserta didik, khususnya tingkat SMP/MTs, dapat memahami dan memiliki pengetahuan yang seoptimal mungkin sesuai kecepatan belajarnya masingmasing sehingga mereka dapat menyelesaikan program pendidikan yang dijalaninya.

Seorang guru bukan hanya bertugas mengajar (teaching), tetapi lebih ditekankan pada membelajarkan (learning) dan mendidik. Pembelajaran yang bisa didapat oleh peserta didik selama dibangku sekolah seharusnya dapat digunakan untuk bekal hidup dan untuk bertahan hidup, oleh karena itu pembelajaran tidak hanya ditetapkan pada keilmuannya semata akan tetapi diharapkan dapat diaplikasikan dalam kehidupan sehari- hari.

Semua materi penjasorkes penting untuk dipelajari peserta didik SMP/MTs karena setiap materi memberikan pengalaman gerak yang berbeda- beda pada peserta didik, namun kenyataan di lapangan menunjukkan bahwa tidak semua materi pelajaran diminati, misalnya materi atletik nomor lari cepat / sprint. Hal ini dapat dilihat dari indikasi sebagai berikut: (1) 
saat guru menyampaikan materi pelajaran yang akan diajarkan atletik (lari cepat / sprint), spontan peserta didik, berkata pak kita belajar bola voli atau sepak bola saja pak, dan sebagainya, (2) saat di lapangan dan memberi tanda untuk membentuk barisan atau kelompok memulai proses pembelajan, peserta didik kadang kurang merespon, (3) banyak peserta didik yang mengambil kesempatan untuk beristirahat, dan (4) peserta didik ada yang tampak malas melakukan aktivitas pembelajaran. Hal seperti ini sangat berpengaruh terhadap hasil belajar penjasorkes. Sedangkan materi yang diminati siswa di antaranya adalah: permainan, senam irama/ aerobik, dan aktivitas pengembangan. Lari cepat/ sprint merupakan salah satu bagian dari olahraga, atletik juga merupakan materi pelajaran yang penting, namun kurang diminati oleh peserta didik. Kurang berminatnya peserta didik terhadap materi lari cepat/ sprint ini disebabkan oleh beberapa hal di antaranya adalah: (1) proses pembelajarannya cenderung terkomando, (2) kurang memberi kebebasan terhadap peserta didik untuk berekspresi, (3) proses pembelajaran cenderung berulang- ulang secara monoton, (4) lari cepat/ sprint tidak ada waktu bermain.

Pembelajaran lari cepat / sprint dengan cara konvensional yakni dengan menggunakan metode hitungan untuk menuntun setiap tahap gerakan teknik lari cepat / sprint, yang selama ini dilakukan kurang dapat mengaktifkan peserta didik dalam mengikuti pembelajaran. Hal ini dapat dilihat dari indikasi sebagai berikut: banyak peserta didik yang ogah- ogahan dalam mengikuti pembelajaran, banyak peserta didik yang mencuri- curi kesempatan untuk beristirahat, dan muncul peryataan- peryataan yang bermakna kurang suka. Kurang aktifnya peserta didik dalam pembelajaran berakibat rendahnya hasil belajar materi lari cepat/ sprint. Berdasarkan data hasil belajar peserta didik pada tahun- tahun sebelumnya nilai rata- rata kelas dari ujian utama lari cepat/ sprint cenderung rendah yakni berada di sekitar Kreteria Ketuntasan Minimal (KKM), bahkan kadang- kadang berada di bawah KKM. Penilaian kepada peserta didik sering dilanjutkan dengan mengadakan perbaikan (remedial), agar semua dapat mencapai kriteria ketuntasan minimal.

Pembelajaran lari cepat / sprint, dengan cara konvensional yang kurang diminati oleh peserta didik seperti tersebut di atas, maka guru memandang perlu untuk mencoba memperbaikinya dengan menggunakan pendekatan lain. Pendekatan baru dalam pembelajaran lari cepat / sprint tersebut dinamakan sirkuit run 20 meter tukar tempat. Oleh karena kemampuan peserta didik yang berbeda- beda dalam menerima informasi dan contoh yang telah diberikan oleh guru menyebabkan berbeda- beda pula keterampilan peserta didik memperagakan unjuk kerja meskipun waktu dan suasana belajar sama. Perbedaan keterampilan unjuk kerja ini dapat diminimalkan apabila teman yang memiliki kemampuan lebih baik membimbing dan mengajari temannya untuk dapat melakukan unjuk kerja yang lebih baik.

\section{Metode Penelitian}

Penelitian ini merupakan Penelitian Tindakan Kelas (PTK) atau classroom action research (CAR) yang berfokus pada upaya untuk memperbaiki kondisi nyata dalam pembelajaran yang kurang baik agar menjadi pembelajaran yang lebih baik dan bermutu. Penelitian ini dilaksanakan dalam dua siklus.

Subjek penelitian adalah peserta didik kelas IX- D putra dan putri di MTs.Negeri Model Sorong. Objek penelitian meliputi seluruh proses pembelajaran dan hasil belajar peserta didik pada mata pelajaran Penjasorkes pokok bahasan Atletik. 
Perencanaan meliputi penyusunan berbagai perangkat pembelajaran yang diperlukan seperti rencana program pelajaran, silabus dan sistem penilaian serta jenis- jenis tagihan yang digunakan. Selain itu, perencanaan juga dilakukan dengan menyusun pedoman pengamatan sirkuit run 20 meter tukar tempat, minat, etika dan moral, dan penilaian psikomotor peserta didik serta penyusunan rencana refleksi, evaluasi dan tindak lanjut. Tindakan kegiatan ini dilakukan oleh peneliti dengan melakukan tindakan pembelajaran sesuai dengan perencanaan. Refleksi kegiatan ini dilaksanakan oleh peneliti dan peserta didik segera setelah pembelajaran selesai. Dalam refleksi dilakukan pengajuan data temuan selama monitoring. Evaluasi kegiatan evaluasi dilakukan berdasarkan temuan hasil refleksi yang dianalisis untuk ditetapkan mana yang perlu direvisi dan mana yang tidak dan tindak lanjut hasil evaluasi ditindak lanjuti sebagai masukan untuk siklus berikutnya. Tindakan pada siklus II merupakan modifikasi dari tindakan yang diberikan pada siklus I dengan memperhatikan hasil evaluasi.

Instrumen yang digunakan dalam penelitian ini adalah instrumen penelitian adalah merupakan rancangan penelitian yang digunakan oleh peneliti untuk mencapai tujuan penelitian yang telah dirumuskan sebelumnya. Jenis penelitian ini adalah penelitian deskriptif. Dalam penelitian ini, peneliti tidak melakukan ujicoba alat yang dipakai dalam pelaksanaan penelitian, karena dalam penelitian deskriptif hanya mengumpulkan data dari tes yang dilaksanakan oleh sampel. Bentuk non tes yakni bentuk instrumen yang berupa lembar pengamatan keterampilan dan penguasaan teknik dasar. Lembar observasi guru, diisi oleh kolaborator dengan memberikan tanda checklist $(\sqrt{ })$. Lembar observasi peserta didik, diisi oleh peneliti dengan memberikan tanda checklist $(\sqrt{ })$.

Selama proses pembelajaran berlangsung dalam keseluruhan siklus. Data diambil dengan menggunakan instrumen yang telah dirancang dan dipersiapkan sebelumnya. Analisis data juga dilakukan secara kontinu selama kegiatan penelitan dilaksanakan. Hasil akhir analisis data berupa rekapitulasi menyeluruh dari proses analisis data. Keseluruhan hasil diperoleh setelah seluruh siklus selesai dilaksanakan dan digunakan untuk menjawab permasalah yang diajukan.

\section{Hasil dan Pembahasan}

\section{a. Perencanaan Pembahasan}

Perencanaan merupakan persiapan mengajar yang berisi hal- hal yang perlu dan harus dilakukan sebelum melaksanakan kegiatan pembelajaran guna mempermudah pelaksanaan kegiatan belajar mengajar. Persiapan tersebut antara lain meliputi: pemilihan materi, metode, media dan alat evaluasi yang akan digunakan. Unsur- unsur tersebut harus mengacu pada silabus yang ada dan mencakup berbagai aspek sebagai berikut: a. penjabaran isi yang tertuang dalam pedoman khusus penyusunan silabus, b. penyesuaian pendekatan dan metode, penggunaan sarana dalam proses belajar dan waktu, c. pengelolaan pembelajaran, d. pelaksanaan proses belajar mengajar dan e. cara menentukan ketercapaian tujuan dan penilaian terhadap proses belajar mengajar. Mengacu pada berbagai aspek tersebut, maka sebelum kegiatan pembelajaran dilakukan, peneliti menyusun berbagai perangkat pembelajaran yang diperlukan seperti rencana program pembelajaran, silabus dan sistem penilaian dan jenis- jenis tagihan yang akan digunakan secara lengkap dapat dilihat pada lampiran 1, lampiran 2 dan lampiran 3. 


\section{b. Pelaksanaan Tindakan}

Setelah proses penyusunan program pembelajaran selesai maka langkah berikutnya adalah tindakan pembelajaran atau tahap pelaksanaan tindakan. Kegiatan pembelajaran pada siklus I ini dilakukan peneliti dengan memanfaatkan halaman / lapangan sekolah. Adapun tatap muka atau pertemuan kegiatan belajar mengajar dalam siklus I dilaksanakan dalam satu pertemuan dengan pertemuan I melakukan pengamatan keterampilan dan penguasaan teknik dasar peserta didik. Adapun jadwal kegiatan secara lengkap dapat dilihat pada lampiran 4.

\section{c. Hasil Refleksi}

Kegiatan refleksi dilakukan oleh guru dan peserta didik segera setelah kegiatan pembelajaran dilakukan. Berdasarkan hasil refleksi terhadap kegiatan pembelajaran yang telah dilakukan selama siklus I diperoleh bahwa peserta didik merasa lebih senang dengan kegiatan pembelajaran yang dilakukan karena tidak membosankan dan peserta didik merasa makin memahami dengan lebih baik. Namun demikian, peserta didik masih merasa terbebani dengan adanya tugas- tugas yang diberikan. Adapun bagi guru, kegiatan pembelajaran yang dilakukan cukup membuat peran guru sebagai fasilitator berjalan dengan baik karena suasana belajar yang menyenangkan. Namun demikian kegiatan pembelajaran ini terasa sangat memerlukan kreatifitas guru yang cukup besar dan waktu lebih banyak terutama dalam melakukan kegiatan penilaian hasil belajar peserta didik yang meliputi berbagai aspek yang diukur yakni aspek kognitif, aspek afektif dan aspek psikomotor serta pengamatan keterampilan dan penguasaan.

\section{d. Hasil Evaluasi Siklus I}

Kegiatan evaluasi meliputi aspek kognitif, aspek afektif dan aspek psikomotor, keterampilan dan penguasaan yang dilakukan selama kegiatan pembelajaran berlangsung. Penilaian terhadap aspek afektif yng berupa minat yang meliputi: ke Taqwaan, kerapian, kehadiran, bertanya, buku catatan, kelengkapan buku catatan, membaca buku diperpustakaan, partisipasi dalam kelompok belajar, etika dalam menyampaikan pendapat dan kerapian tugas. Adapun aspek afektif yang berupa etika dan moral meliputi: datang ke sekolah tidak terlambat, berpakaian rapi sesuai seragam sekolah, mengucapkan salam saat bertemu, teliti melakukan tugas, berdoa sebelum belajar, berbicara dengan santun, siap sedia untuk membantu, merapikan tempat duduk, menjaga kebersihan dan selalu berjamaah sholat, serta yang nasrani rajin beribadah ke gereja. Penilaian terhadap aspek psikomotorik meliputi: menyiapkan alat sendiri, melakukan pengamatan, memasang alat ukur, membaca hasil pengukuran. Adapun penilaian terhadap aspek kognitif dilakukan dengan pemberian, tugas individu, tugas kelompok. Pengamatan keterampilan dan penguasaan teknik dasar, dilakukan dengan mengamati keterampilan dan penguasaan teknik dasar general (aspek kesadaran diri, aspek berpikir rasional, aspek sosial), dan keterampilan akademik serta penguasaan akademik.

Secara lengkap hasil belajar peserta didik selama siklus I dapat dilihat pada lampiran 1. Adapun secara ringkas dapat dilihat pada Tabel 1 dan Tabel 2 sebagai berikut: 
Tabel 1

Ringkasan Hasil Belajar Peserta didik Kelas IX- D Putra Pada Siklus I

\begin{tabular}{cc|cccc}
\hline & & & \multicolumn{2}{c}{ ASPEK } & \\
No & Kognitif & Afektif & Psikomotorik & Keterampilan Penguasaan \\
\hline $\mathbf{1}$ & 4,40 & B & B & Baik \\
$\mathbf{2}$ & 6,90 & A & A & Baik Sekali \\
$\mathbf{3}$ & 6,00 & B & B & Baik \\
$\mathbf{4}$ & 5,00 & A & A & Baik Sekali \\
$\mathbf{5}$ & 5,30 & B & B & Baik \\
$\mathbf{6}$ & 5,00 & B & B & Baik \\
$\mathbf{7}$ & 4,50 & B & B & Baik \\
$\mathbf{8}$ & 6,20 & A & A & Baik Sekali \\
$\mathbf{9}$ & 5,40 & A & B & Baik \\
$\mathbf{1 0}$ & 6,40 & B & B & Baik \\
\hline \multicolumn{7}{c}{ Rerata: } & A:4 Peserta & A:3 Peserta & Baik Sekali:3 Peserta \\
& 5,51 & didik(40\%) & didik(30\%) & didik (30\%) \\
& & B:6 Peserta & B:7 Peserta & Baik: 7 Peserta didik(70\%) \\
\hline
\end{tabular}

Tabel 2

Ringkasan Hasil Belajar Peserta didik Kelas IX- D Putri Pada Siklus I

\begin{tabular}{|c|c|c|c|c|}
\hline No & Kognitif & Afektif & $\begin{array}{l}\text { ASPEK } \\
\text { Psikomotorik }\end{array}$ & $\begin{array}{c}\text { Keterampilan } \\
\text { Penguasaan }\end{array}$ \\
\hline 1 & 6,00 & A & A & Baik Sekali \\
\hline 2 & 7,00 & $\mathrm{~A}$ & A & Baik Sekali \\
\hline 3 & 6,00 & $\mathrm{~A}$ & A & Baik Sekali \\
\hline 4 & 5,30 & A & A & Baik Sekali \\
\hline 5 & 4,50 & B & B & Baik \\
\hline 6 & 6,00 & A & B & Baik \\
\hline 7 & 4,10 & B & B & Baik \\
\hline 8 & 4,70 & B & B & Baik \\
\hline 9 & 6,00 & A & A & Baik Sekali \\
\hline 10 & 5,50 & A & B & Baik \\
\hline 11 & 6,50 & A & A & Baik Sekali \\
\hline 12 & 5,20 & A & B & Baik \\
\hline 13 & 4,40 & B & B & Baik \\
\hline 14 & 5,00 & B & A & Baik \\
\hline 15 & 4,50 & A & B & Baik \\
\hline \multirow[t]{2}{*}{16} & 5,40 & B & $\mathrm{B}$ & Baik \\
\hline & $\begin{array}{c}\text { Rerata: } \\
5,38\end{array}$ & $\begin{array}{c}\text { A:10 Peserta } \\
\text { didik }(62,50 \%) \\
\text { B:6 Peserta } \\
\operatorname{didik}(37,50 \%)\end{array}$ & $\begin{array}{c}\text { A:7 Peserta } \\
\operatorname{didik}(43,75 \%) \\
\text { B:9 Peserta } \\
\operatorname{didik}(56,25 \%)\end{array}$ & $\begin{array}{l}\text { Baik Sekali: } 8 \\
\text { Peserta didik }(, 50 \%) \\
\text { Baik: } 8 \text { Peserta } \\
\operatorname{didik}(50 \%)\end{array}$ \\
\hline
\end{tabular}


Berdasarkan tabel 1 di atas menunjukkan bahwa hasil belajar peserta didik putra pada aspek kognitif diperoleh rata- rata nilai 5,51, pada aspek afektif dengan kriteria baik (A), ada 4 peserta didik (40\%), dan kriteria cukup (B), ada 6 peserta didik (60\%), pada aspek psikomotorik dengan kriteria baik (A), ada 3 peserta didik (30\%), dan kriteria cukup (B), ada 7 peserta didik (70\%), pada aspek keterampilan dan penguasaan dengan kriteria baik sekali ada 3 peserta didik (30\%), dan kriteria baik 7 peserta didik (70\%). Adapun berdasarkan tabel 2 menunjukkan bahwa hasil belajar untuk peserta didik putri, pada aspek kognitif diperoleh rata- rata nilai 5,38. Pada aspek afektif dengan kriteria baik (A), ada 10 peserta didik $(62,50 \%)$, dan kriteria cukup (B), ada 6 peserta didik (37,50\%), pada aspek psikomotorik dengan baik (A), ada 7 peserta didik (43,75\%), dan kriteria cukup (B), ada 9 peserta didik $(56,25 \%)$, dan aspek keterampilan dan penguasaan dengan kriteria baik sekali ada 8 peserta didik $(50 \%)$, dan kriteria baik 8 peserta didik $(50 \%)$.

Berdasarkan seluruh temuan selama siklus I, terdapat beberapa masukan yang perlu diperhatikan dan dipertimbangkan untuk lebih baiknya kegiatan pembelajaran pada siklus II, berbagai masukan tersebut antara lain adalah lebih diperbanyak lagi kegiatan demonstrasi, lebih diperbanyak latihan teknik dasar dan tidak terlalu banyak ceramahnya.

\section{Hasil Kegiatan Pembelajaran Siklus II}

\section{a. Perencanaan Pembelajaran}

Kegiatan pembelajaran pada siklus II, dilaksanakan mengacu pada perencanaan pembelajaran yang telah disusun sebelum kegiatan pembelajaran dimulai. Namun demikian, terdapat berbagai perubahan pada kegiatan pembelajaran yang dilakukan, mengingat dan mempertimbangkan berbagai masukan dari pelaksanaan siklus I. Perubahan tersebut terutama dilakukan pada perbaikan metode dan suasana pembelajaran seperti kegiatan demonstrasi yang lebih menarik, memperbanyak latihan teknik dasar terutama terkait dengan keterampilan dan penguasaan teknik dasar, tanpa mengurangi ketercapaian standar kompetensi yang harus dicapai para peserta didik, serta pemberian tugas secara lebih proporsional.

\section{b. Pelaksanaan Tindakan}

Kegiatan pembelajaran pada siklus II, dilakukan peneliti dalam satu pertemuan dengan pertemuan tersebut adalah pelaksanaan tes keterampilan dan penguasaan teknik dasar. Jadwal kegiatan secara lengkap dapat dilihat pada lampiran 3. Kegiatan pembelajaran pada sikjus II, ini juga dilakukan peneliti dengan memanfaatkan lapangan/ halaman sekolah.

\section{c. Hasil Refleksi}

Sebagaimana siklus I, kegiatan refleksi pada siklus II, dilakukan oleh guru dan peserta didik segera setelah kegiatan pembelajaran dilakukan. Berdasarkan hasil refleksi terhadap kegiatan pembelajaran yang telah dilakukan selama siklus II, diperoleh bahwa peserta didik merasa sangat senang dan nyaman dengan kegiatan pembelajaran yang dilakukan karena tidak membosankan dan peserta didik merasa makin memahami materi dengan lebih baik. Selain itu, peserta didik juga merasa tidak terbebani lagi dengan berbagai tugas yang diberikan karena sudah terbiasa dan dibuat lebih proporsional. Para peserta didik juga mengharapkan agar suasana belajar dan metode pembelajaran seperti ini diterapkan lagi untuk pembelajaran selanjutnya. 
Adapun bagi guru, kegiatan pembelajaran yang dilakukan terasa cukup efektif dan efisien, baik dari sisi waktu maupun ketercapaian standar kompetensi. Selain itu, peran guru sebagai fasilitator dapat dilakukan dengan lebih baik karena seluruh proses pembelajaran benar- benar terpusat pada peserta didik bukan pada guru. Dibutuhkannya kreatifitas guru yang lebih baik dalam mengelola kelas justru menjadikan guru semakin terpacu untuk meningkatkan proses pembelajaran yang dilakukan terutama mengingat respon peserta didik yang sangat baik. Adanya penilaian hasil belajar peserta didik yang meliputi berbagai aspek kognitif, aspek afektif dan aspek psikomotorik serta pengamatan keterampilan dan penguasaan teknik dasar juga terasa manusiawi dan menyeluruh dalam mengungkap kompetensi yang telah dicapai para peserta didik.

\section{d. Hasil Evaluasi Siklus II}

Kegiatan evaluasi pada siklus II, juga meliputi aspek kognitif, aspek afektif dan aspek psikomotorik serta keterampilan dan penguasaan teknik dasar yang dilakukan selama kegiatan pembelajaran berlangsung. Penilaian terhadap aspek afektif juga meliputi aspek minat, etika dan moral peserta didik selama kegiatan pembelajaran seperti pada siklus I. Penilaian terhadap aspek psikomotorik pada siklus II, agak berbeda dengan siklus I karena materi yang berbeda pula. Pada siklus II, penilaian pada aspek psikomotorik meliputi kesiapan melakukan lari cepat/ sprint, melakukan start, dan memasuki garis finish. Adapun penilaian terhadap aspek kognitif sebagaimana pada siklus I, dilakukan dengan tugas individu dan tugas kelompok. Pada siklus II, frekuensi kegiatan pembelajaran lebih tertata atau lebih proporsional sehingga tidak terlalu menjadi beban bagi para peserta didik.

Secara lengkap hasil belajar peserta didik selama kegiatan pembelajaran pada siklus II, dapat dilihat pada lampiran 2. Adapun secara ringkas disajikan pada tabel 3 dan tabel 4 sebagai berikut:

Tabel 3

Ringkasan Hasil Belajar Peserta didik Kelas IX- D Putra Pada Siklus II

\begin{tabular}{ccccc}
\hline No & Kognitif & Afektif & $\begin{array}{c}\text { ASPEK } \\
\text { Psikomotorik }\end{array}$ & $\begin{array}{c}\text { Keterampilan } \\
\text { Penguasaan }\end{array}$ \\
\hline $\mathbf{1}$ & 6,40 & A & A & Baik Sekali \\
$\mathbf{2}$ & 6,90 & A & A & Baik Sekali \\
$\mathbf{3}$ & 5,70 & B & A & Baik \\
$\mathbf{4}$ & 6,20 & A & A & Baik Sekali \\
$\mathbf{5}$ & 5,50 & A & B & Baik \\
$\mathbf{6}$ & 6,30 & A & A & Baik Sekali \\
$\mathbf{7}$ & 4,90 & B & B & Baik \\
$\mathbf{8}$ & 6,30 & A & A & Baik Sekali \\
$\mathbf{9}$ & 6,80 & A & A & Baik Sekali \\
$\mathbf{1 0}$ & 6,60 & A & A & Baik Sekali \\
\hline & Rerata: & A:8 Peserta & A:8 Peserta & Baik Sekali:7 \\
& 6,16 & didik $(80 \%)$ & didik $(80 \%)$ & Peserta didik (70\%) \\
& & B:2Peserta & B:2Peserta & Baik:3 Peserta \\
& & didik(20\%) & didik(20\%) & didik(30\%) \\
\hline
\end{tabular}


Tabel 4

Ringkasan Hasil Belajar Peserta didik Kelas IX- D Putri Pada Siklus II

ASPEK

\begin{tabular}{ccccc} 
No & Kognitif & Afektif & Psikomotorik & $\begin{array}{c}\text { Keterampilan } \\
\text { Penguasaan }\end{array}$ \\
\hline $\mathbf{1}$ & 6,30 & A & A & Baik Sekali \\
$\mathbf{2}$ & 7,10 & A & A & Baik Sekali \\
$\mathbf{3}$ & 6,40 & A & B & Baik Sekali \\
$\mathbf{4}$ & 6,30 & A & A & Baik Sekali \\
$\mathbf{5}$ & 5,30 & B & A & Baik \\
$\mathbf{6}$ & 7,00 & A & B & Baik Sekali \\
$\mathbf{7}$ & 5,50 & A & B & Baik Sekali \\
$\mathbf{8}$ & 4,70 & B & A & Baik \\
$\mathbf{9}$ & 6,00 & A & B & Baik Sekali \\
$\mathbf{1 0}$ & 6,50 & A & A & Baik Sekali \\
$\mathbf{1 1}$ & 6,30 & A & A & Baik Sekali \\
$\mathbf{1 2}$ & 5,30 & A & B & Baik Sekali \\
$\mathbf{1 3}$ & 5,20 & B & A & Baik \\
14 & 5,60 & A & A & Baik Sekali \\
$\mathbf{1 5}$ & 4,80 & A & B & Baik \\
$\mathbf{1 6}$ & 5,50 & B & A & Baik \\
\hline \multicolumn{7}{c}{ Rerata: } & A:12 Peserta A:10 Peserta & Baik Sekali: 11 Peserta \\
& 5,70 & didik(77\%) & didik(62,50\%) didik (68,75\%) \\
& & B:4 Peserta & B:6 Peserta & Baik: 5 Peserta didik \\
& & didik(23\%) & didik(37,50\%) & $(31,25 \%)$ \\
\hline
\end{tabular}

Berdasarkan tabel 3 di atas menunjukkan bahwa hasil belajar peserta didik putra pada aspek kognitif diperoleh rata- rata nilai 6,16, pada aspek afektif dengan kriteria baik (A), ada 8 peserta didik (80\%), dan kriteria cukup (B), ada 2 peserta didik (20\%), pada aspek psikomotorik dengan kriteria baik (A), ada 8 peserta didik (80\%), dan kriteria cukup (B), ada 2 peserta didik (20\%), pada aspek keterampilan dan penguasaan dengan kriteria baik sekali ada 7 peserta didik (70\%), dan kriteria baik 3 peserta didik (30\%). Adapun berdasarkan tabel 4 menunjukkan bahwa hasil belajar untuk peserta didik putri, pada aspek kognitif diperoleh rata- rata nilai 5,70, pada aspek afektif dengan kriteria baik (A), ada 12 peserta didik (77\%), dan kriteria cukup (B), ada 4 peserta didik (23\%), pada aspek psikomotorik dengan baik (A), ada 10 peserta didik (62,50\%), dan kriteria cukup (B), ada 6 peserta didik $(37,50 \%)$, dan pada aspek keterampilan dan penguasaan dengan kriteria baik sekali ada 11 peserta didik $(68,75 \%)$, dan kriteria baik 5 peserta didik $(31,25 \%)$.

Berdasarkan pengalaman dan hasil yang diperoleh selama kegiatan pembelajaran, sebagaimana baik pada siklus I, maka pada siklus II, ini terdapat beberapa masukan dari para peserta didik yang perlu diperhatikan dan dipertimbangkan yakni digunakannya pendekatan dan metode pembelajaran seperti yang telah dilaksanakan pada pembelajaran- pembelajaran materi berikutnya. 


\section{Perbandingan Hasil Belajar Peserta Didik}

Perbandingan hasil belajar peserta didik dilakukan untuk mengetahui efektifitas kegiatan pembelajaran yang dilakukan. Kegiatan perbandingan hasil belajar peserta didik dilakukan dengan membandingkan hasil belajar pada siklus I, dan siklus II. Van De Walle (1990) mengatakan bahwa perbandingan merupakan pasangan terurut dari bilanganbilangan atau ukuran- ukuran yang digunakan untuk membandingkan bilangan- bilangan atau ukuran- ukuran tersebut. Hal ini sama dengan pendapat Siswono dan Lastiningsih (2007:172) yang menjelaskan bahwa perbandingan merupakan suatu pernyataan untuk membandingkan suatu besaran dengan besaran lain. Perbandingan hasil belajar peserta didik pada siklus I dan siklus II, dapat dilihat pada Tabel 5 dan tabel 6 sebagai berikut:

Tabel 5

Perbandingan Hasil Belajar Peserta didik IX-D Putra antara Siklus I dan Siklus II

Siklus

\section{Aspek}

\begin{tabular}{|c|c|c|c|c|c|c|c|}
\hline \multirow[t]{2}{*}{ Siklus } & \multirow[t]{2}{*}{ Kognitif } & \multicolumn{2}{|c|}{ Afektif } & \multicolumn{2}{|c|}{ Psikomotorik } & \multicolumn{2}{|c|}{$\begin{array}{c}\text { Keterampilan } \\
\text { dan Penguasaan }\end{array}$} \\
\hline & & A & B & A & B & $\begin{array}{l}\text { Baik } \\
\text { Sekali }\end{array}$ & Baik \\
\hline I & 5,51 & $\begin{array}{c}4 \\
(40 \%)\end{array}$ & $\begin{array}{c}6 \\
(60 \%)\end{array}$ & $\begin{array}{c}3 \\
(30 \%)\end{array}$ & $\begin{array}{c}7 \\
70 \%)\end{array}$ & $\begin{array}{c}3 \\
(30 \%)\end{array}$ & $\begin{array}{c}7 \\
(70 \%)\end{array}$ \\
\hline II & 6,16 & $\begin{array}{c}8 \\
(80 \%)\end{array}$ & $\begin{array}{c}2 \\
(20 \%)\end{array}$ & $\begin{array}{c}8 \\
(80 \%)\end{array}$ & $\begin{array}{c}2 \\
(20 \%)\end{array}$ & $\begin{array}{c}7 \\
(70 \%)\end{array}$ & $\begin{array}{c}3 \\
(30 \%)\end{array}$ \\
\hline
\end{tabular}

Tabel 6

Perbandingan Hasil Belajar Peserta didik VII-B Putri antara Siklus I dan Siklus II

\begin{tabular}{cccccccc} 
Siklus & \multicolumn{9}{c}{ Aspek } \\
& Kognitif & \multicolumn{2}{c}{ Afektif } & \multicolumn{2}{c}{ Psikomotorik } & \multicolumn{2}{c}{$\begin{array}{c}\text { Keterampilan dan } \\
\text { Penguasaan } \\
\text { Baik }\end{array}$} \\
& & \multicolumn{2}{c}{ Baik } \\
& & A & B & A & B & Sekali & \\
\hline I & 5,38 & 10 & 6 & 7 & 9 & 8 & 8 \\
II & 5,70 & $(62,50 \%)$ & $(37,50 \%)$ & $(43,75 \%)$ & $(56,25 \%)$ & $(50 \%)$ & $(50 \%)$ \\
& & $(77 \%)$ & $(23 \%)$ & $(62,50 \%)$ & $(37,50 \%)$ & $(68,75 \%)$ & $(31,25 \%)$ \\
\hline
\end{tabular}

Berdasarkan tabel diatas tampak bahwa terjadi peningkatan hasil belajar peserta didik pada keseluruhan aspek peningkatan masing- masing aspek adalah sebagai berikut: 1 . Peserta didik putra: kognitif $(0,06)$, afektif $(29,21 \%$ untuk kriteria baik (A), yang disertai penurunan 29,21\% untuk kriteria cukup (B), psikomotorik 17,85\% untuk kriteria baik (A), yang disertai penurunan 17,85\% kriteria cukup (B), keterampilan dan penguasaan $17,44 \%$ untuk kriteria baik sekali yang disertai penurunan 17,44\% untuk kriteria baik). 2. Peserta didik putri: kognitif $(0,15)$, afektif $(22,41 \%$ untuk kriteria baik (A), yang disertai penurunan $22,41 \%$ untuk kriteria cukup (B), psikomotorik 14,65\% untuk kriteria baik (A), yang disertai 
penurunan 14,65\% kriteria cukup (B), keterampilan dan penguasaan 17,64\% untuk kriteria baik sekali yang disertai penurunan $17,64 \%$ untuk kriteria baik).

\section{Kesimpulan dan Saran}

\subsection{Kesimpulan}

Berdasarkan hasil nilai dan pengamatan sikap setiap siklus dan pembahasan yang telah disajikan dapat ditarik kesimpulan dan saran sebagai berikut :

1. Strategi pembelajaran Sirkuit Run 20 meter tukar tempat dapat meningkatkan keterampilan dan penguasaan teknik dasar, dapat memecahkan masalah penjasorkes pada materi teknik dasar atletik, lari cepat/ sprint di kelas IX-D MTs.Negeri Model Sorong. Pada siklus 1 ketuntasan kelas secara klasikal adalah 66,7\% meningkat menjadi $85 \%$ pada siklus 2 . Sedangkan secara individu, dari 26 peserta didik, terdapat 5 peserta didik yang belum mencapai nilai minimal 75 , tetapi mereka sudah mengalami peningkatan nilai. Untuk kelima peserta didik ini diberikan pembelajaran remedial yang dilaksanakan setelah penelitian ini.

2. Tingkat partisipasi peserta didik dalam kegiatan pembelajaran lebih aktif dibanding guru sebagai narasumber dan pemimpin (leader).

3. Interaksi sesama peserta didik lebih hidup karena saat temannya melakukan atau memperaktikkan yang lain memperhatikan dan mengoreksi kesalahan yang dilakukan. Berbeda kalau proses pembelajaran berpusat pada guru, ketika teman melakukan unjuk kerja teman yang lain tidak memperhatikan karena tidak mempunyai tanggung jawab mengoreksi temannya.

4. Tingkat ketuntasan belajar peserta didik mencapai $90 \%$ tetapi perlu ditambah dengan metode lain sehingga siswa yang remedial tidak ada dan yang perlu pengayaan lebih sedikit.

\subsection{Saran}

Metode pembelajaran melalui sirkuit run 20 meter tukar tempat bisa diterapkan pada seluruh kompetensi dasar (KD) atau materi pembelajaran Penjasorkes. Pihak sekolah diharapkan memperhatikan sarana dan prasarana sehingga proses pembelajaran dapat dilaksanakan lebih efektif, lancar dan baik sesuai yang direncanakan. Hasil penelitian ini semoga dapat menjadi salah satu acuan bagi sekolah dan pihak- pihak lain yang memerlukan. 


\section{Daftar Pustaka}

Kemmis, Stephen dan MC Taggart, Robin (eds), (1998). The action

Research Planner, Third Edition, Australia : Deakin University Production Unit.

Permen Diknas RI Nomor 23. (2006). Standar kompetensi lulusan untuk satuan pendidikan dasar dan menengah. Jakarta: Mendiknas.

Lampiran II Kepmendikbud Nomor 060/U/1993 Tanggal 25 Pebruari.(1993). Kurikulum pendidikan dasar, GBPP SLTP. Mata pelajaran Penjaskes. Jakarta: Depdikbud.

Bucher, C.A. (1983). Foundations of physical education \& sport (6th ed). London: The C.V. Mosby Company.

Yudha M. Saputra. (2001).Dasar-dasar keterampilan atletik pendekatan bermain untuk sekolah lanjutan tingkat pertama. Jakarta: Depdiknas Dirjen Dikdasmen Dirjen Olahraga.

Depdiknas.2004.Pedoman Pengembangan Instrumen dan Penilaian

Psikomotor. Jakarta ; Proyek Peningkatan Mutu SLTP.

Polya. 1981. How to Solve It. Princetown, NJ: Pricetown University Press.

Solso, Robert L. 2008. Psikologi Kognitif, Edisi Kedelapan. Jakarta: Erlangga.

Siswono, Tatag Y. E. 1999. "Metode Pemberian Tugas Pengajuan Soal (Problem Posing) dalam Pembelajaran Matematika Pokok Bahasan Perbadingan di MTs Negeri Rungkut Surabaya”. Tesis Program Pasca Sarjana, IKIP Surabaya 